Коць Михайло

кандидат психологічних наук, доцент доцент кафедри педагогічної та вікової психології Східноєвропейського національного університету імені Лесі Українки

http://orcid.org/0000-0002-5607-0564

Цвігун Ольга здобувач першого(бакалаврського) ступеня факультету психології та соціології Східноєвропейського національного університету імені Лесі Українки

DOI https://doi.org/10.35619/prap_rv.vi14.160

\title{
ПСИХОЛОГІЧНИЙ АНАЛІЗ ЕМОЦІЙНОГО ВИГОРАННЯ У СТУДЕНТСЬКОЇ МОЛОДІ
}

\begin{abstract}
Анотація. У статті здійснено теоретичний аналіз та емпіричне дослідження особливостей впливу емочійного вигорання на особистість студентів технічного університету. Доведено, щуо поняття емочійне вигорання студентів постає як низка взаємопов'язаних чинників, які визначають діяльність особистості. Обгрунтовано, щуо синдром емочійного виснаження варто розглядати як процес поступової втрати особою емоційної, когнітивної та фізичної енергії, який вказує на симптоми розумового виснаження, фізичної втоми і зниженням мотивації до навчання.

Мета дослідження полягає у вивченні особливостей синдрому емоційного вигорання студентів технічного університету. У емпіричному досліджені було використано методику «Діагностики рівня емоиійного вигорання» Бойка, щэо є найбільш комплексною $і$ дає можливість системно $і$ детальніме проаналізувати такі компоненти симптомів синдрому «вигорання»: напруження; резистениія; виснаження. 3 а допомогою методики «Визначення психічного «вигорання» Рукавішнікова дослідили прояви синдрому за такими основними показниками: психоемочійне виснаження; особистісне віддалення; професійна мотивачія. Результати емпіричного дослідження виявили, щуо у студентів технічного університету не виявлено повністю сформованих симптомів емочійного вигорання та є проблеми лише з мотивачійною сферою професійного розвитку. Результати дослідження відображають лише окремий аспект впливу отримання академічних знань на емочійне виснаження студентської молоді і висвітлюють лише частину наявної проблеми, яка, безумовно, заслуговує на подальше дослідження. Зокрема, нами планується детальне дослідження різних компонентів, щуо формують синдром емоційного вигорання та їх взаємодію з умовами отримання академічних знань.
\end{abstract}

Ключові слова: студентська молодь, емочійне вигоряння, стрес, мотивація.

Постановка проблеми. Науковий інтерес до проблеми емоційного вигорання пояснюється тим, що значно збільшилась кількість людей, які почуваються знесиленими та емоційно виснаженими. Це, врешті решт позначається на продуктивності діяльності та якості життя конкретних верств населення. У вітчизняній та зарубіжній літературі є низка досліджень синдрому емоційного вигорання. Безліч наукових доробків з точки зору потенційного розвитку даного синдрому у особистостей, які вже отримали освіту та мають певний стаж роботи. Ми ж зацікавлені у вивченні цього феномену на початку професійного становлення майбутнього фахівця. Зокрема, науковий інтерес представляють дослідження студентів, які отримують академічні знання у технічному університеті, оскільки інтенсивні інтелектуальні навантаження можуть спричиняти ознаки емоційного вигорання.

Аналіз останніх досліджень 3 проблеми. На теперішній час у літературних джерелах досить вибірково висвітлюється проблема емоційного вигорання у студентської молоді. Так, 
зокрема, Бойко (1996, 2008), Водоп`янова (2008), Зайчикова (2005) досліджували феномен емоційного та психічного вигорання загалом або як складову професійного виснаження. Вірна (2003), Яворовська, Камишнікова, Яновська (2013) зробили акцент на дослідження психологічних особливостей становлення особистості студента. На сьогоднішній день поняття емоційного вигорання має вже діагностичний статус «Z 73.0 Вигорання, стан життєвого виснаження» у Міжнародному статистичному класифікаторі захворювань та проблем, пов'язаних зі здоров'ям (International Statistical Classification of Diseases and Related Health Problems 10th Revision (ICD-10)2015-WHO Version for; 2015). Результати досліджень Бойка вказують на те, що емоційне вигорання - це механізм психологічного захисту особистості, що проявляється у вигляді повного або часткового виключення емоцій у відповідь на постійний психотравмуючий вплив $(1996,2008)$.

Досі точно не відомо, що саме є основною причиною емоційного вигорання. Це можуть бути як особистісні характеристики людини, так і організаційні. Зазвичай вигорання розцінюється як реакція особистості на стрес у відповідь на певні вимоги. Тривале чи різке порушення внутрішнього балансу призводить до «вигорання» особистості. Досить часто цей стан пов'язують із професійною діяльністю (Варнава, 2006). Але розвиток емоційного вигорання не обмежується лише професійним середовищем та проявляється у різних життєвих ситуаціях людини. Під час отримання академічних знань студенти постійно перебувають у стані стресу. Це наслідок постійної втоми, емоційної спустошеності, сумнівів чи правильну професію було обрано і так далі. Все це може стати причиною емоційного вигорання ще не сформованого спеціаліста.

На думку дослідника, причиною виникнення емоційного вигорання є зміна соціальноекономічних умов в суспільстві. Створюються проблеми скорочення робочих місць, у невпевненості стабільності соціального й матеріального становища. Також, поряд з цим виникає певна конкуренція за високооплачувану і престижну професію, нині швидшає темп зміни запитів на ринку праці. Такі умови призводять до прояву стану емоційного, психічного, і фізичного виснаження, також виявляється тривога, депресія, психосоматичні розлади та залежність від психоактивних речовин. Виходячи зі сказаного вище, можна стверджувати, що синдром емоційного виснаження це процес поступової втрати особою емоційної, когнітивної та фізичної енергії, настання розумового виснаження, фізичної втоми та зниження навчальної мотивації

Мета дослідження полягає у вивченні особливостей синдрому емоційного вигорання у студентів технічного вищого навчального закладу.

Виклад основного матеріалу дослідження. У емпіричному досліджені було використано методику «Діагностики рівня емоційного вигорання» ( авт. Бойко), що $є$ найбільш комплексною і дає можливість системно і детальніше проаналізувати такі компоненти симптомів синдрому «вигорання»: напруження; резистенція; виснаження. За допомогою методики «Визначення психічного «вигорання» (авт. Рукавішнікова) досліджувалися прояви синдрому за такими основними показниками: психоемоційне виснаження; особистісне віддалення; професійна мотивація. Дослідження проводилось на базі Луцького національного технічного університету. Вибірка складала 30 студентів різних факультетів.

Після проведення методики «Діагностики емоційного вигорання» реципієнти, які брали участь у дослідженні були розподілені на декілька підгрупу за кількістю отриманих балів. Як видно з рисунку 1 у наших респондентів синдром емоційного вигорання чітко не простежується.

Зокрема, компонент «Напруження» у половини студентів (56\%), у третини учасників (37\%) цей показник знаходиться на стадії формування. Найбільш негативні показники щодо напруження простежені лише у окремих учасників. Наявність цих тенденцій свідчить про те, що у більшої частини опитуваних відсутне відчуття емоційного виснаження, втоми, що викликана власною навчальною діяльністю. У компоненті «Резистенція» показники мають явні відмінності. У $60 \%$ реципієнтів він знаходиться у стадії формування, у 30\% не сформувався та у $10 \%$ сформувався. Такі показники вказують на те, що у домінуючої частки досліджуваних можуть проявлятися симптоми надмірного емоційного виснаження, які можуть провокувати виникнення та розвиток захисних реакцій та які роблять людину відстороненою та байдужою. А будь яка навчальна діяльність може викликати у студентів відчуття надмірної перевтоми. У компоненті «Виснаження» в 57\% опитуваних він не сформований, у 40\% формується та лише у $3 \%$ сформований. Це означає, що саме в цих студентів не проявляються симптоми психофізичної 
перевтоми. Але деякі з них можуть переконуватися у тому, що вони спустошені чи надто цинічно ставляться до навчання

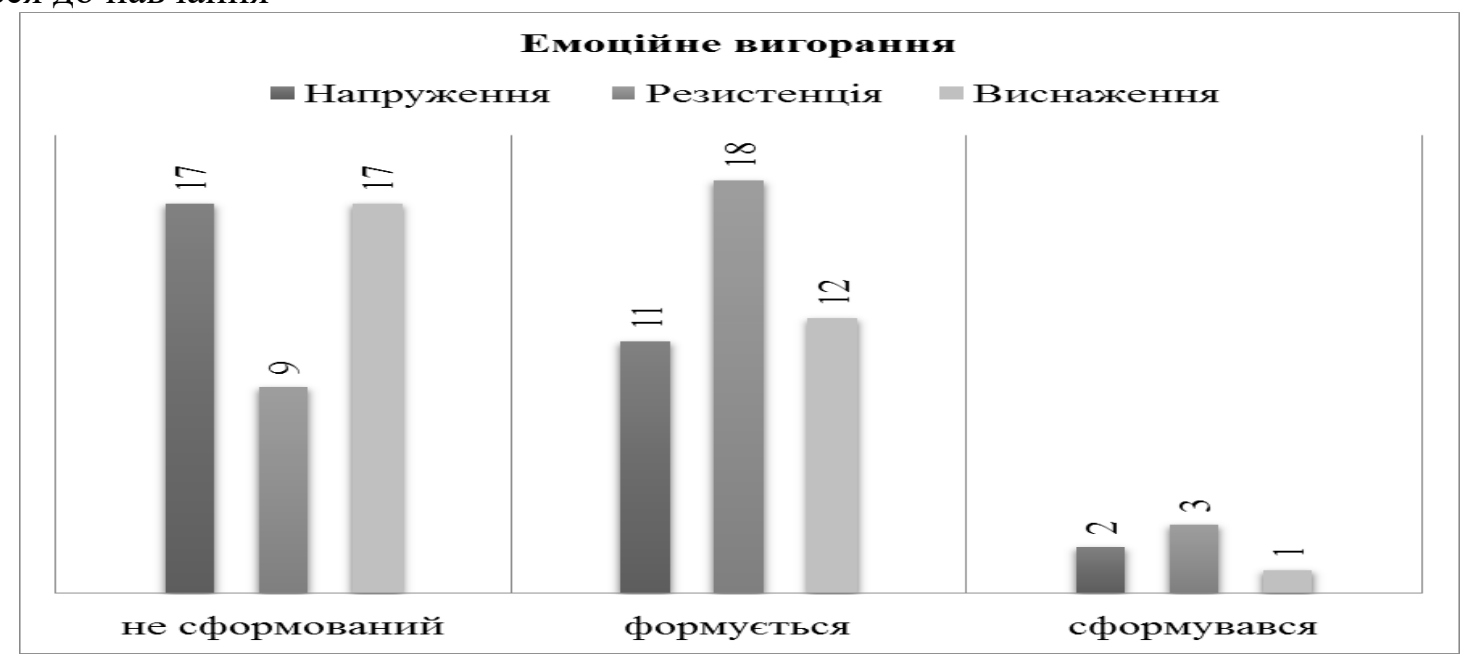

Рис. 1. Числовий розподіл показників компонентів емоційного вигорання студентської молоді (за методикою Бойка)

Після проведення методики «Визначення психічного вигорання» Рукавішнікова реципієнти, які брали участь у дослідженні були розподілені за кількістю отриманих балів у числовому відношенні (рис. 2.).

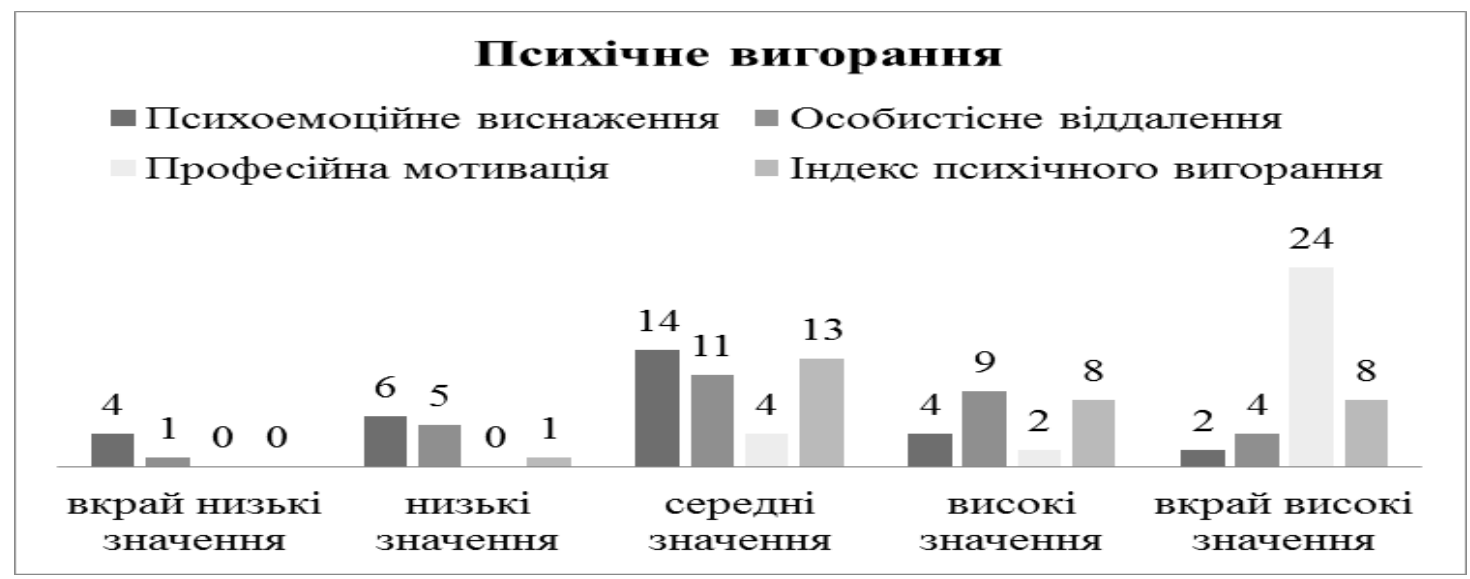

Рис. 2. Числовий розподіл показників рівнів психічного вигорання студентської молоді (за методикою Рукавішнікова)

Отже, за даними методики зрозуміло, що у $27 \%$ реципієнтів рівень психічного вигорання вкрай високий. У $43 \%$ середні показники та у $3 \%$ низькі. Це свідчить про те, що синдром емоційного вигорання у студентської молоді, які навчаються у технічному закладі вищої освіти знаходиться на стадії формування. Розглянемо показники шкал, які формують емоційне вигорання детальніше.

Психоемоційне виснаження - це процес вичерпання емоційних, фізичних та енергетичних ресурсів особистості. У міжособистісних стосунках проявляється через психічне виснаження, роздратованість, агресію, підвищену чутливість до критики з боку оточуючих. На особистісному рівні можливі такі прояви психічного вигорання, як тривожність та низька емоційна толерантність. Небажання йти на навчання, бажання швидше завершити робочий день, прогули - це все симптоми емоційного виснаження на мотиваційному рівні. Дивлячись на показники (рис. 3), можна чітко відстежити, що більшою мірою у студентів цей аспект психічного вигорання ще формується, адже середні значення простежуються майже у половини респондентів (47\%). 


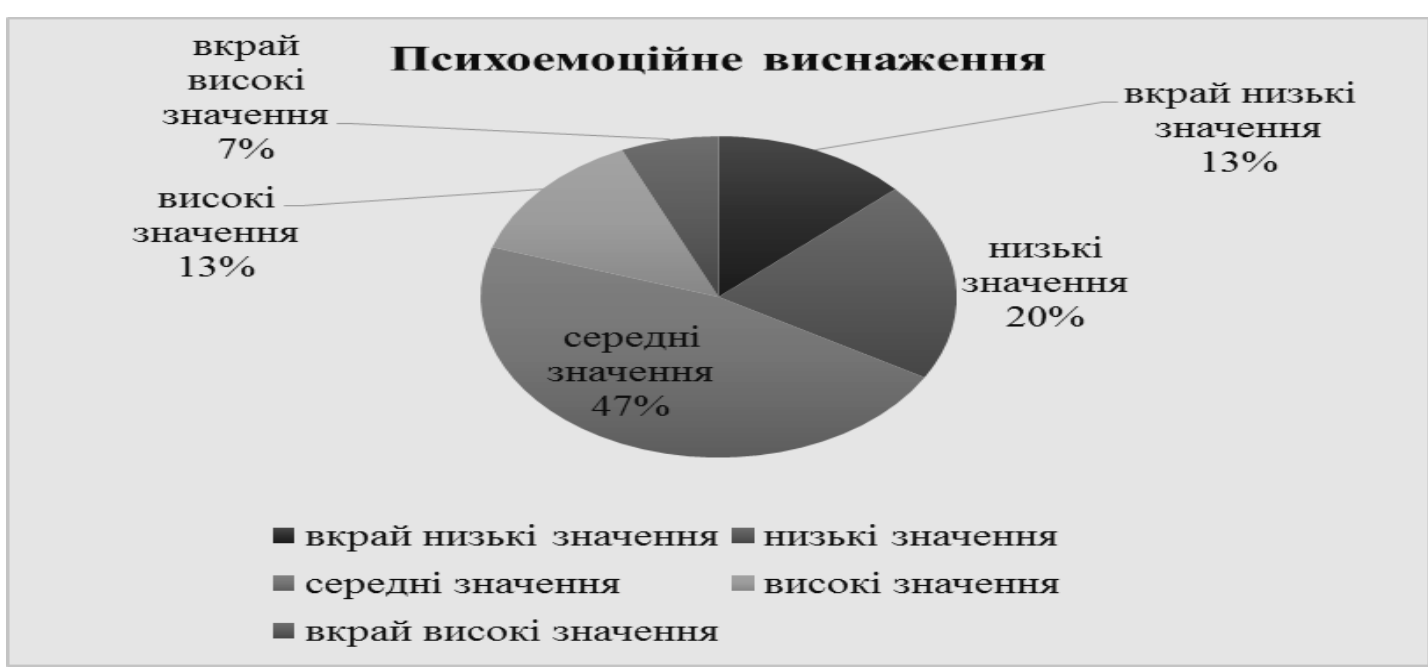

\section{Рис. 3. Відсотковий розподіл показників за шкалою «Психоемоційне виснаэсеня» (за методика Рукавішнікова)}

Висновки і перспективи подальших розвідок. Проаналізовано особливості впливу емоційного вигорання на особистість студентів технічного університету. Доведено, що поняття емоційне вигорання студентів постає як низка взаємопов'язаних чинників, які визначають діяльність особистості. Здійснено емпіричне дослідження сформованості фаз і стадій синдрому емоційного вигорання серед студентської молоді Результати емпіричного дослідження виявили, що у студентів технічного університету не виявлено повністю сформованих симптомів емоційного вигорання та є проблеми з мотиваційною сферою професійного розвитку. Результати дослідження відображають лише окремий аспект впливу отримання академічних знань на емоційне виснаження студентської молоді і висвітлюють лише частину наявної проблеми, яка, безумовно, заслуговує на подальше дослідження. Зокрема, нами планується детальне дослідження різних компонентів, що можуть спричиняти формування синдрому емоційного вигорання та їх взаємодію з умовами отримання академічних знань.

\section{СПИСОК ПОСИЛАНЬ}

Бойко, В. В. (2008). Синдром эмочионального выгорания: диагностика и профілактика. СанктПетербург: Питер.

Бойко, В. В. (1996). Энергия эмочиий в общении: взгляд на себя и на других. Москва: Наука.

Варнава, У. В. (2006). Экспериментальное исследование незрелих психологических защит личности. Наукові записки Інституту психології імені Г. С. Костюка АПН України, 29, 102-106.

Вірна, Ж. П. (2003). Мотиваційно-смислова регуляиія у професіоналізації психолога. Луцьк: Вежа.

Гірняк, К. М. (2015). Причини емоційного вигорання особистості: теоретичний аспект управління. Науковий вісник Львівського національного університету ветеринарної медицини та біотехнологій імені Гюицького, 17, 1(4), 183-188. Взято 3 http://nbuv.gov.ua/UJRN/nvlnu_2015_17_1(4)_36

Зайчикова, Т. В. (2005). Сочіально-психологічні детермінанти синдрому «професійного вигорання» у вчителів. (Дис. канд. психол. наук). Інститут психології імені Г. С. Костюка АПН України, Київ.

Яворовська, Л. М., К Камишнікова, Р. Ф., Поліванова, О. С., Яновська, С. Г., \& Куделко, С. М. (2013). Психологічні особливості студентського віку. На допомогу кураторам. Харків: ХНУ імені В. Н. Каразіна.

\section{REFERENCES}

Bojko, V. V. (2008). Sindrom jemocional'nogo vygoranija: diagnostika i profilaktika [Emotional burnout syndrome: diagnosis and prevention]. Sankt-Peterburg: Piter. [in Russian].

Bojko, V. V. (1996). Jenergija jemocij v obshhenii: vzgljad na sebja i na drugih [The energy of emotions in communication: a look at yourself and others]. Moskva: Nauka. [in Russian]. 
Varnava, U. V. (2006). Jeksperimental'noe issledovanie nezrelih psihologicheskih zashhit lichnosti [Experimental study of immature psychological defenses of personality]. Naukovi zapiski Institutu psihologi imeni G. S. Kostjuka APN Ukraïni, 29, 102-106. [in Russian].

Virna, Zh. P. (2003). Motivacijno-smislova reguljacija u profesionalizaciï psihologa [Motivational and semantic regulation in the professionalization of the psychologist]. Luc'k: Vezha. [in Ukrainian].

Girnjak, K. M. (2015). Prichini emocijnogo vigorannja osobistosti: teoretichnij aspekt upravlinnja [Causes of emotional burnout of the personality: theoretical aspect of management]. Naukovij visnik L'vivs'kogo nacional'nogo universitetu veterinarnoï medicini ta biotehnologij imeni Gzhic'kogo, 17, 1(4), 183-188. Vzjato z http://nbuv.gov.ua/UJRN/nvlnu_2015_17_1(4)_36 [in Ukrainian].

Zajchikova, T. V. (2005). Social'no-psihologichni determinanti sindromu «profesijnogo vigorannja» $u$ vchiteliv [Socio-psychological determinants of teachers' burnout syndrome]. (Dis. kand. psihol. nauk). Institut psihologiï imeni G. S. Kostjuka APN Ukraïni, Kiïv. [in Ukrainian].

Javorovs'ka, L. M., Kamishnikova, R. F., Polivanova, O. C., Janovs'ka, S. G., \& Kudelko, S. M. (2013). Psihologichni osoblivosti students'kogo viku. Na dopomogu kuratoram [Psychological features of student age. To help the curators]. Kharkiv: HNU imeni V. N. Karazina. [in Ukrainian].

\title{
PSYCHOLOGICAL ANALYSIS OF OCCUPATIONAL BURNOUT AMONG STUDENT YOUTH
}

\author{
Mykhailo Kots \\ Candidate of Psychological Sciences, \\ Associate Professor of the Department of Educational \\ and Age Psychology, Lesya Ukrainka Eastern European \\ National University \\ http://orcid.org/0000-0002-5607-0564
}

Olha Tsvihun

student of the Department of Psychology and Sociology,

Lesya Ukrainka Eastern European National University DOI https://doi.org/10.35619/prap_rv.vi14.160

Abstract. Theoretical analysis and empirical study on characteristics of an influence of occupational burnout on a personality of students of a technical university is carried out in this article. It is proved that the concept of occupational burnout of students appears as a number of interrelated factors that determine an activity of the individual. It is substantiated that occupational burnout should be considered as a process of gradual loss of the emotional, cognitive and physical energy, which indicates symptoms of mental exhaustion, physical fatigue and decreased motivation to study. The purpose of the study is to observe peculiarities of occupational burnout syndrome among students of the technical university. The empirical study used the method of "Diagnosis of occupational burnout" by V. Boyko, which is the most complex and allows to analyze systematically and thoroughly the following components of burnout syndrome symptoms: stress, resistance, exhaustion. We investigated the manifestations of the syndrome by the following main indicators: psycho-emotional exhaustion, personal alienation, professional motivation using the method of "Determination of mental burnout" by O. Rukavishnikov.

The study was conducted at Lutsk National Technical University. The sample consisted of 30 students from different faculties. The results of the empirical study revealed that students of the technical university did not have fully formed symptoms of occupational burnout and had problems only with the motivational sphere of professional development.

The results of the study reflect only a single aspect of the impact of academic knowledge on the emotional exhaustion among student youth and highlight only part of a problem that certainly deserves further study.In particular, we plan a detailed study of the various components that form the syndrome of occupational burnout and their interaction with the conditions for obtaining academic knowledge.

Key words: student youth, occupational burnout, stress, motivation. 